
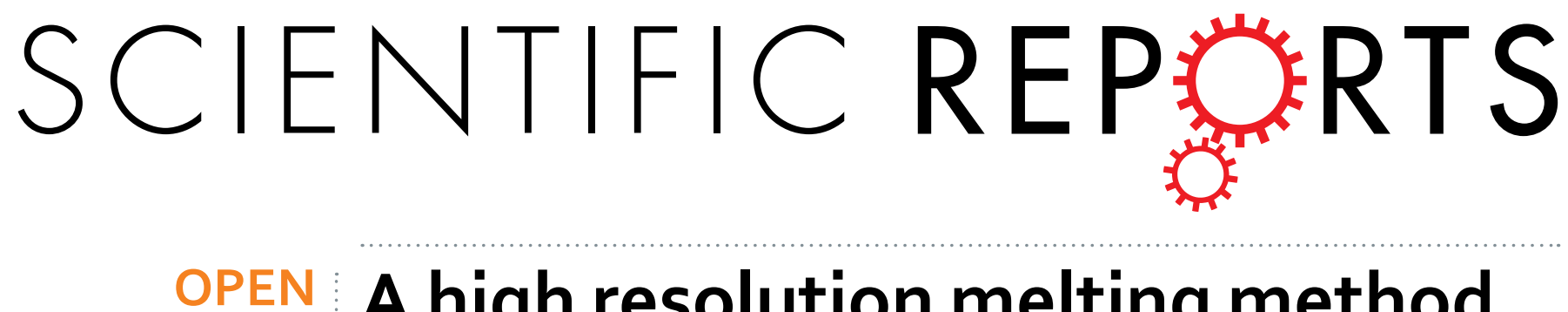

A high resolution melting method for the molecular identification of the potentially toxic diatom

Received: 13 July 2016

Accepted: 11 May 2017

Published online: 26 June 2017

\section{Pseudo-nitzschia spp. in the Mediterranean Sea}

\author{
Laura Pugliese ${ }^{1}$, Silvia Casabianca ${ }^{1,2}$, Federico Perini ${ }^{1}$, Francesca Andreoni ${ }^{1}$ \& Antonella \\ Penna ${ }^{1,2,3}$
}

The aim of this study was to develop and validate a high resolution melting (HRM) method for the rapid, accurate identification of the various harmful diatom Pseudo-nitzschia species in marine environments. Pseudo-nitzschia has a worldwide distribution and some species are toxic, producing the potent domoic acid toxin, which poses a threat to both human and animal health. Hence, it is important to identify toxic Pseudo-nitzschia species. A pair of primers targeting the LSU rDNA of the genus Pseudo-nitzschia was designed for the development of the assay and its specificity was validated using 22 control DNAs of the $P$. calliantha, $P$. delicatissima/P. arenysensis complex and $P$. pungens. The post-PCR HRM assay was applied to numerous unidentified $P$ seudo-nitzschia strains isolated from the northwestern Adriatic Sea (Mediterranean Sea), and it was able to detect and discriminate three distinct Pseudo-nitzschia taxa from unidentified samples. Moreover, the species-specific identification of Pseudo-nitzschia isolates by the HRM assay was consistent with phylogenetic analyses. The HRM assay was specific, robust and rapid when applied to high numbers of cultured samples in order to taxonomically identify Pseudonitzschia isolates recovered from environmental samples.

Diatoms (class Bacillariophyceae) are among the most productive eukaryotic microalgae. They are found in oceans around the world and play a fundamental role in global biogeochemical cycles ${ }^{1}$. Within the Bacillariophyceae class, the genus Pseudo-nitzschia is found in polar, temperate, subtropical and tropical regions ${ }^{2}$, although some Pseudo-nitzschia species are limited to distinct regional areas. Among the more than 37 species identified worlwide ${ }^{3}$, at least 12 Pseudo-nitzschia species are toxic. These species produce domoic acid (DA), a neurotoxin causing amnesic shellfish poisoning (ASP), which is responsible for many toxic blooms worldwide ${ }^{2}$. Blooms of Pseudo-nitzschia spp. can be stimulated by nutrient (mainly nitrate and phosphate) input from various sources, such as upwelling, turbulence or riverine inputs, deriving largely from anthropogenic nutrient loads of agricultural and sewage origins ${ }^{4}$. However, Pseudo-nitzschia blooms or occurrences are often a seasonal phenomenon in many coastal sites, and the frequency of toxic blooms generated by several species of Pseudo-nitzschia is increasing in various coastal areas worldwide ${ }^{2}$. The impact of DA is evident in the marine food web. In fact, DA has been detected in the tissues of many invertebrates, fish, birds and marine mammals ${ }^{5-7}$. In Canada in 1987 consumption of contaminated seafood ${ }^{8}$ caused a serious outbreak of ASP resulting in human mortality. However, since this dramatic episode, there have been no reports of human deaths caused by ASP thanks to the institution of effective monitoring programs. Nevertheless, DA occurrence can have negative economic impact on shellfish aquaculture farms, since the molluscan shellfish remain the only known vector of DA to humans.

The regions that are most affected by DA are Northern Europe, Canada and Northern United States. Low levels of DA have been detected in the Mediterranean Sea, but its presence has not been associated with harmful

${ }^{1}$ Department of Biomolecular Sciences, University of Urbino, Viale Trieste 296, 61121, Pesaro, Italy. ${ }^{2}$ Conisma, Consorzio Interuniversitario per le Scienze del Mare, Pz. Flaminio 9, 00196, Rome, Italy. ${ }^{3} \mathrm{CNR}-$ Institute of Marine Sciences (ISMAR), Largo Fiera della Pesca, 60125, Ancona, Italy. Correspondence and requests for materials should be addressed to A.P. (email: antonella.penna@uniurb.it) 
blooms. However, various Pseudo-nitzschia species, such as P. brasiliana, $P$. calliantha, $P$. galaxiae, $P$. multistriata and $P$. pseudodelicatissima have been found toxic ${ }^{9-13}$. Furthermore, today, several species of $P$ seudo-nitzschia pose a contamination risk along the coast of North Africa. The northern Adriatic Sea (Mediterranean Sea) is a high mesotrophic area strongly influenced by inputs from the Po River, which sustains blooms dominated by numerous frequently occurring diatom species with considerable biomass, including various Pseudo-nitzschia spp. with an abundance range of $10^{4}-10^{5}$ cells $1^{-114-16}$. The most frequently occurring species are $P$. delicatissima complex, $P$. seriata complex, $P$. calliantha, $P$. pungens, $P$. fraudulenta ${ }^{17}, 18$, and toxic blooms have recently been linked to ASP toxin or DA accumulation in Adriatic shellfish ${ }^{19-21}$. However, in the NW Adriatic Sea, this genus is more widespread than other potentially harmful phytoplankton taxa, therefore, it is important to check the DA levels associated to Pseudo-nitzschia species blooms or occurrences.

Multiple toxigenic Pseudo-nitzschia species frequently coexist in the same environment, even during bloom events that appear to be dominated by a single species ${ }^{8}$. Since the genus Pseudo-nitzschia includes a large number of species, their accurate taxonomical identification is important because they can be associated with domoic acid production ${ }^{3}$. To date, species identification or description has often been performed by integrating different methodological approaches based on scanning and transmission electron microscopy, and molecular analyses. However, the light microscopy does not always provide the resolution required for the identification of various Pseudo-nitzschia species ${ }^{22,23}$. Further, despite concerted efforts, the taxonomy of Pseudo-nitzschia has still being updated, and new morphological species complexes and/or cryptic and pseudo-cryptic species (i.e. P. delicatissima or P. pseudodelicatissima complex) have recently been described within the genus ${ }^{24,25}$. Molecular taxonomy studies based on different genetic markers, including ribosomal RNA gene (LSU) and internal transcribed spacers (ITS regions), cytochrome oxidase 1 ( $\operatorname{cox} 1)$ and chloroplast genes of ribulose 1,5 biphosphate carboxylase ( $\mathrm{rbcl}$ ), have uncovered numerous cases of genetically distinct, and at times reproductively isolated, groups of strains or genetic lineages that could not be easily distinguished with light microscopy ${ }^{26-28}$.

Recent molecular approaches, such as $\mathrm{qPCR}^{13,29,30}$, ARISA $^{31}$, microarray ${ }^{32-34}$ and dot blot hybridization systems ${ }^{35}$ have been used for specific and sensitive Pseudo-nitzschia species identification and/or quantification from clonal cultures and field samples ${ }^{36}$. These methods are essentially based on the evaluation of the sequence variation and design of oligonucleotide primers and/or probes in target nucleotide regions and they allow the accurate identification of various species. Among the molecular techniques used to analyze small genetic mutations, such as single nucleotide polymorphisms (SNPs), we find the post PCR high resolution melting (HRM) curve analysis. This technique is based on the melting properties of double-stranded DNA (dsDNA). Different melting profiles are obtained from the transition of dsDNA to denaturated single-stranded DNA (ssDNA) as a result of a gradual temperature increase after PCR amplification. Both processes, PCR and gradual denaturation, take place in the same tube during a real-time run lasting less than two hours. The recent development of HRM was made possible by a new generation of dyes designed for this technique and technological improvements in real-time PCR instruments. The HRM method has mainly been used for genotyping microrganisms $\mathrm{s}^{37-40}$ and it is considered the simplest method for genotyping and detecting mutations since it can be performed immediately after qPCR. This post PCR HRM assay can provide higher throughput and specificity at a lower cost and with reduced analysis time of the cultured sample examination compared to qPCR, microarray or rDNA sequencing. In fact, a single HRM reaction can process many samples simultaneously. Moreover, the melting HRM profiles seem to be more specific than some probe signals, and because of the high throughput analysis, the HRM assay has lower costs than PCR and sequencing reactions.

In this study, the first molecular assay based on HRM curve analysis was developed and applied to detect three different potentially toxic Pseudo-nitzschia species, such as $P$. calliantha, P. delicatissima complex and P. pungens, which are very common in the NW Adriatic Sea. These species are always retrieved in blooming events and/ or occurrences of mixed diatom species ${ }^{18}$ in this area of the Mediterranean where aquaculture farming is widespread. Hence, these species pose a potential risk of the DA accumulation in molluscan shellfish, although to date, DA levels of $P$. delicatissima complex are low ${ }^{13}$.

Several cultured strains of Pseudo-nitzschia spp., isolated from seawater samples, were analyzed by the post PCR HRM assay, which yielded precise accurate identification of three distinct species of Pseudo-nitzschia based on the different melting curve profiles that were generated. The HRM-based identifications were also confirmed by phylogenetic analyses based on both LSU and ITS rDNA sequences.

This newly developed method proved to be specific, accurate and rapid in discriminating numerous cultured isolates of the Pseudo-nitzschia species or complex, which are very difficult to identify using traditional light microscopy. Knowledge of the diverse composition of potentially toxic Pseudo-nitzschia spp. can provide information on the presence and frequency of target species in regional coastal waters in the NW Adriatic Sea. Such information can be important for the management of harmful algal blooms occurring in areas where molluscan shellfish farms are widespread.

\section{Methods}

Sampling, isolation and cultures. The sampling sites were located $3000 \mathrm{~m}$ off the Italian coast (northwestern Adriatic Sea) at Tavollo $\left(43^{\circ} 59^{\prime} .30 \mathrm{~N} ; 12^{\circ} 46^{\prime} .42 \mathrm{E}\right)$, Foglia $\left(43^{\circ} 56^{\prime} .55 \mathrm{~N} ; 12^{\circ} 56^{\prime} .18 \mathrm{E}\right)$ and Metauro $\left(43^{\circ} 50^{\prime} .54 \mathrm{~N}\right.$; $\left.13^{\circ} 05^{\prime} .9 \mathrm{E}\right)$ river transects. Several strains of $P$. calliantha, $P$. delicatissima, $P$. cf. arenysensis and $P$. pungens isolated $500 \mathrm{~m}$ off the coast of Pesaro in 2009, 2010 and 2013, as described in Penna et al. ${ }^{13}$, were used for the HRM assay development (Table S1). An additional 29 Pseudo-nitzschia strains were isolated from net samples using single cell isolation technique during the period from November 2014 to March 2015 (see Results section). All isolates were maintained in $\mathrm{f} / 2$ medium $^{41}$ at $16 \pm 1^{\circ} \mathrm{C}$ on a $12: 12 \mathrm{~h}$ light:dark cycle, at an irradiance of $100 \mu \mathrm{moL}$ photons $\mathrm{m}^{-2} \mathrm{~s}^{-1}$

Light microscopy (LM) observations of living cells were carried out using an Axiovert 40 CFL, Zeiss at 200x and 400x magnifications. 
Forward primer

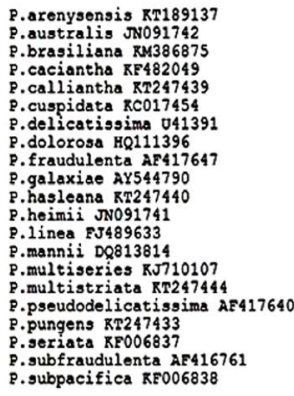

Target specific region

Reverse primer

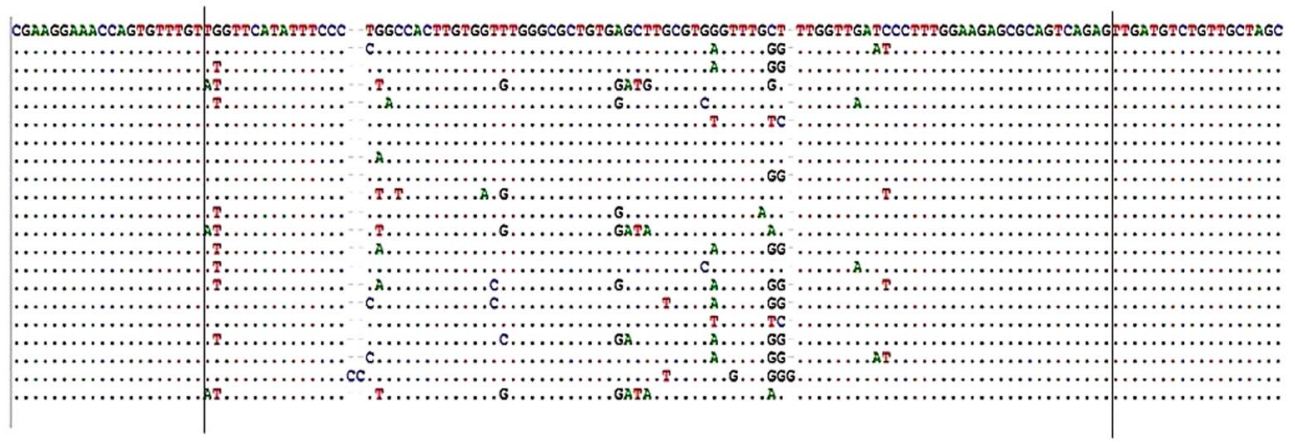

Figure 1. The alignment of consensus LSU rDNA sequences of 21 Pseudo-nitzschia species. The sequences were aligned using the Bioedit Sequence Alignment v. 7.0.5.3. The common forward and reverse primers flanked species-specific regions of the 21 Pseudo-nitzschia species considered under investigation. The target LSU rDNA amplified region was $130-133 \mathrm{bp}$ in length and located in the 384 to 514 nucleotide position.

Genomic DNA extraction. Exponential phase cultures of Pseudo-nitzschia spp. were harvested by centrifugation at $4,000 \mathrm{xg}$ for $20 \mathrm{~min}$ at room temperature. Total genomic DNA was extracted from pellets using the DNeasy Plant Kit (Qiagen, Valencia, CA, USA) according to the manufacturer's instructions. DNA integrity was assessed by electrophoresis on agarose gel $(0.8 \% \mathrm{w} / \mathrm{v})$ and visualized by standard ethidium bromide staining under UV light. Quantification was performed using a Qubit fluorometer with a Quant-iT dsDNA HS Assay Kit (Invitrogen, Carlsbard, CA, USA).

HRM primer design and specificity. A total of 21 LSU rDNA sequences of various Pseudo-nitzschia species mainly present in the Mediterranean Sea (Fig. 1) ${ }^{25}, 42,43$, available in GenBank, were aligned using the BioEdit Sequence Alignment Editor v. 7.0.5.3 ${ }^{44}$, to check for a SNP-carrying region flanked by highly conserved sequences suitable for primer design. The primers were designed using Primer-BLAST ${ }^{45}$. The primers for the amplification of the $130-133 \mathrm{bp}$ fragment, which was positioned from the 384 to 514 nucleotide position, were HRM_PSEUDO_F forward (5'-GCGAAGGAAACCAGTGTTTGT-3') and HRM_PSEUDO_R reverse (5'-GCTAGCAACAACAGACATCAACTCT-3'). The primers were synthesized by Eurofins MWG Operon (Ebersberg, Germany). The Pseudo-nitzschia primer specificity was examined in silico using BLAST and tested in qPCR with both target and various purified genomic DNAs of Pseudo-nitzschia spp. including P. calliantha, P. delicatissima, $P$. cf. arenysensis, $P$. pungens, $P$. fraudulenta, $P$. multistriata and $P$. pseudodelicatissima, which are common in the northwestern Adriatic Sea. The specificity of the assay was also evaluated using the DNA of other 23 phytoplankton taxa comprising other 6 diatom species, 14 dinoflagellate species and 3 species of Raphidophyceae. The PCR protocol is described below. The melting curve analysis was performed to check primer dimers and PCR products from misannealed primers. The PCR products were electrophoresed and analyzed on $1.8 \%(\mathrm{w} / \mathrm{v})$ agarose gel. The amplified PCR fragments were sequenced by GATC Biotech AG, Köln, Germany to confirm the target specific DNA fragment. Each PCR reaction testing the specificity of the assay was performed in duplicate.

qPCR HRM assay. The qPCR HRM assay was performed in a final volume of $25 \mu$ l containing primers at final concentrations of $500 \mathrm{nM}$ and $200 \mu \mathrm{M}$ of each GeneAmp dNTP; $1.5 \mathrm{mM} \mathrm{MgCl}_{2}$; 1 X Reaction AmpliTaq Gold 360 Buffer; 1X Reaction MeltDoctor HRM Dye, (MeltDoctor ${ }^{\mathrm{TM}}$ HRM Dye, a stabilized form of the fluorescent SYTO ${ }^{\circledR} 9$ double-stranded nucleic acid stain), $1.25 \mathrm{U}$ of AmpliTaq Gold 360 DNA Polymerase (Applied Biosystems, Foster City, CA, USA), and 1 ng of DNA template. PCR was carried out using the StepOne Real-Time PCR System (Applied Biosystems, Foster City, CA, USA). The thermal cycling conditions consisted of $10 \mathrm{~min}$ at $95^{\circ} \mathrm{C}$, followed by $40 \mathrm{cycles}$ at $95^{\circ} \mathrm{C}$ for $10 \mathrm{~s}$ and $60^{\circ} \mathrm{C}$ for $1 \mathrm{~min}$. HRM assay was performed from $60^{\circ} \mathrm{C}$ to $95^{\circ} \mathrm{C}$ with a ramp rate of $0.3 \%$. All PCR experiments were performed in duplicate including target positive controls of P. calliantha CBA72, P. pungens CBA100 and non-template controls (NTC). As P. delicatissima and P. arenysensis shared the same LSU rRNA target amplicon, the $P$. delicatissima CBA144 was used as a control for the $P$. delicatissima/P. arenysensis phylogenetic complex.

The raw melting curve data were processed by the High Resolution Melt Software v. 3.0.1 (Applied Biosystems, Foster City, CA, USA). The pre- and post-melt regions were set as close as possible to the melting transition region. Positive controls, one for each species tested, were set in the HRM software assigning each control to its corresponding well. Samples were analyzed and the software automatically made a call for each sample according to the shape of the melt curves aligned to the controls and the melting temperature $\left(\mathrm{T}_{\mathrm{m}}\right)$.

HRM assay validation and application for Pseudo-nitzschia species identification. The method was validated using several DNAs $(\mathrm{n}=22)$ of Pseudo-nitzschia, already used as controls (as above), such as the target species of the P. calliantha, P. pungens and P. delicatissima/P. cf. arenysensis complex. In particular, 7 strains of each species, as $P$. calliantha, $P$. pungens and $P$. delicatissima, and 1 strain of $P$. cf. arenysensis, were used (Table S1). The method was subsequently applied to 29 strains of unidentified Pseudo-nitzschia spp. isolated from seawater 
off the coast (northwestern Adriatic Sea) between November 2014 and March 2015, as previously described. The HRM assay was applied for taxon-specific identification.

Statistical analyses. HRM data analysis was performed with the Kruskall-Wallis and Mann-Whitney tests to determine whether there were significant differences in the average Tm values among and between the Pseudo-nitzschia spp. isolates. All statistical calculations were performed using PAST ver. 2.17 with a $\mathrm{p}<0.05$ determining significance.

Molecular and phylogenetic analyses. Representative strains of Pseudo-nitzschia spp. identified by the HRM assay were analyzed to confirm the species-specific taxonomical assignment by LSU and ITS5.8S rDNA sequence alignment and phylogenetic analyses. The sequences of ribosomal genes obtained from new Pseudo-nitzschia cultured isolates were deposited in EMBL-EBI-ENA. Other ribosomal sequences of Pseudo-nitzschia spp. isolates were included in this study. All sequences are listed in Table S2. The LSU rDNA was amplified and sequenced using D1R or D2C primers targeting the D1-D2 region of the nuclear LSU rDNA ${ }^{46}$. The ITS region of the rDNA was amplified and sequenced using the universal primer ITSA and ITSB ${ }^{47}$ or ITS1R and ITS $1 F^{48}$. The PCR reaction for the LSU rDNA was as follows: tubes contained $50 \mu$ lof mixture of $200 \mu \mathrm{M}$ of dNTPs; $0.4 \mu \mathrm{M}$ of each primer, $4 \mathrm{mM}$ of $\mathrm{MgCl}_{2}, 1 \mathrm{X}$ reaction buffer (Master TaqBuffer, 5 PRIME, Germany), $1 \mathrm{U}$ Taq DNA Polymerase (5 PRIME, Germany) and 0.5-1 ng DNA template. PCR thermal cycling conditions were as follows: an initial denaturation at $95^{\circ} \mathrm{C}$ for $10 \mathrm{~min}, 35$ cycles of $1 \mathrm{~min}$ at $95^{\circ} \mathrm{C}, 1 \mathrm{~min}$ at $50^{\circ} \mathrm{C}$, and $2.5 \mathrm{~min}$ at $72^{\circ} \mathrm{C}$ and a final extension step of $7 \mathrm{~min}$ at $72^{\circ} \mathrm{C}$. The PCR reaction for the ITS-5.8S rDNA using ITSA and ITSB primers was as follows: tubes contained $50 \mu \mathrm{l}$ of mixture of $200 \mu \mathrm{M}$ of dNTPs; $0.2 \mu \mathrm{M}$ of each primer, $1 \mathrm{mM}$ of $\mathrm{MgCl}_{2}, 0.75 \mathrm{X}$ TaqMasterPCR Enhancer (5 PRIME, Germany), 1X reaction buffer (Master TaqBuffer, 5 PRIME, Germany), 1 U Taq DNA Polymerase (5 PRIME, Germany) and 0.5-1 ng DNA template. The PCR using ITS1R and ITS1F primers was carried out in a mixture as described above, with the following exceptions: $0.4 \mu \mathrm{M}$ of each primer, $4 \mathrm{mM}$ of $\mathrm{MgCl}_{2}$ and 0.5X TaqMasterPCR Enhancer (5 PRIME, Germany). PCR thermal cycling conditions were as follows: an initial denaturation at $95^{\circ} \mathrm{C}$ for $10 \mathrm{~min}, 35 \mathrm{cycles}$ of $30 \mathrm{~s}$ at $94^{\circ} \mathrm{C}, 30 \mathrm{~s}$ at $55^{\circ} \mathrm{C}$ min or $50^{\circ} \mathrm{C}$, and $30 \mathrm{~s}$ at $72^{\circ} \mathrm{C}$ and a final extension step of $10 \mathrm{~min}$ or 2 min at $72^{\circ} \mathrm{C}$.

All PCR amplified products were purified using the MinElute Gel Extraction Kit (Qiagen, Valencia, CA, USA), and the products were directly sequenced with the ABI PRISM BigDye Terminator Cycle Sequencing Kit v. 1.1 on the ABI 310 Genetic Analyzer (Applied Biosystem, Foster City, CA, USA). Standard thermal cycling conditions were used for both templates setting the annealing temperature according to the template $\left(60^{\circ} \mathrm{C}\right.$ and $50^{\circ} \mathrm{C}$ for ITS and LSU PCR specific primers, respectively). Difficult templates and repeated regions were solved increasing initial denaturation time and modifying thermal cycling condition as follows: denaturation at $96^{\circ} \mathrm{C}$ for $10 \mathrm{sec}$ and annealing/extension at $50^{\circ} \mathrm{C}$ for 40 cycles.

The LSU and ITS-5.8S sequences were aligned using MAFFT software. Short aligned sequences and ambiguously aligned positions were excluded from the alignment manually or using Gblocks (http://molevol.cmima. csic.es/castresana/Gblocks.html) with default settings. The neighbor-joining (NJ), maximum parsimony (MP) and maximum likelihood (ML) analyses were performed in MEGA v. $6.06^{49}$. The robustness of the NJ, MP and ML trees was tested by bootstrapping using 1000 pseudo-replicates. Distance and maximum likelihood trees were built based on the substitution model selected through the Akaike Information Criterion option implemented in MEGA v. 6.06. The most appropriate evolutionary models for LSU and ITS-5.8S gene rDNA alignment were found to be $\mathrm{HKY}+\mathrm{G}$ and $\mathrm{HKY}+\mathrm{G}+\mathrm{I}$, respectively. The MP analyses were performed using the Tree-Bisection-Redrafting (TBR) algorithm with search level 1, in which the initial trees were obtained by the random addition of sequences (10 replicates). All positions containing gaps and missing data were eliminated. Bayesian analyses were performed using MrBayes 3.2.3 ${ }^{50}$ with the following settings: four Markov chains were run for 2,000,000 generations with a sampling frequency of 100 generations. Log-likelihood values for sampled trees were stabilized after almost 200,000 generations. The last 18,000 trees were used to estimate Bayesian posterior probabilities, whereas the first 2,001 were discarded as burn-ins. Results from two-independent runs were used to construct a majority-rule consensus tree containing the posterior probabilities.

The sequences of Fragilariopsis rhombica 5-17 AF7656 and Fragilariopsis sp. NL2010 GU170665 were used as an outgroup for the Pseudo-nitzschia LSU and ITS-5.8S gene phylogenetic analyses, respectively.

\section{Results}

HRM primer design and specificity. The Pseudo-nitzschia spp. primers, designed to amplify the target sequence of the LSU rDNA region, were examined in silico using BLAST and they were found to be specific to $P$. calliantha, $P$. delicatissima, $P$. cf. arenysensis and $P$. pungens. No non-specific products were detected, and amplification was not obtained in any template controls (NTCs). According to the in silico analysis, the PCR product size was $130 \mathrm{bp}$. The specificity of the qPCR assay was also tested by using DNA from other Pseudo-nitzschia and microalgal species. Negative amplifications were obtained. All these results showed that the HRM assay was highly specific for targeting the Pseudo-nitzschia species.

Validation of the qPCR HRM assay. The HRM assay proved able to successfully distinguish Pseudo-nitzschia species or complex such as P. calliantha, P. pungens and P. delicatissima/P. cf. arenysensis. All Ct values ranged from 20 to 24 . The melting curve variation of the Pseudo-nitzschia spp. can be plotted in various ways, including aligned and difference plots, according to the melting behavior of their amplicons determined using the High Resolution Melt software ver. 3.0.1 (Applied Biosystems) (Figure S1). As shown in the plots, the melting curves of Pseudo-nitzschia spp. can be distinctly separated by both the silhouettes of the curves and the Tm for each species or complex. Three different average Tm values of $84.56 \pm 0.18 ; 85.22 \pm 0.06 ; 85.05 \pm 0.09$ were assigned to $P$. calliantha, $P$. delicatissima/P. cf. arenysensis and $P$. pungens, respectively. The Tm values were highly 
reproducible across 22 repeated melt curve runs ( 7 and 8 melt curve runs for $P$. calliantha and $P$. pungens and $P$. delicatissima/P. cf. arenysensis, respectively). The Kruskall Wallis test demonstrated that the three Tm values were significantly different $(\mathrm{Hc}=22.32, \mathrm{p}<0.001)$. Moreover, the a posteriori pairwise Mann-Whitney test showed that the differences between Pseudo-nitzschia species were significant with the Bonferroni correction $(\mathrm{p}<0.001)$.

Analysis of Pseudo-nitzschia spp. isolates. The method was subsequently applied for the analysis of unknown isolates of the Pseudo-nitzschia spp., collected between November 2014 and March 2015 in the northwestern Adriatic Sea. A total of 29 Pseudo-nitzschia spp. isolates were analyzed using the qPCR HRM assay. The melting profiles generated by PCR products of unidentified isolates were evaluated, and it was observed that the Pseudo-nitzschia spp. in the unknown strains showed consistency in their corresponding Tm values and curve silhouettes, which were similar to those generated by DNA positive controls. In the end, the melting profile from the isolates could be clustered into three groups using the auto-calling mode of the High Resolution Melt software (Applied Biosystems), and identification of the Pseudo-nitzschia spp. was made by comparing their silhouettes and Tm values to those of controls. The confidence interval for auto-called results ranged between $96-100 \%$ (Fig. 2). A total of 12 strains of $P$. calliantha, 10 strains of $P$. delicatissima/P. cf. arenysensis, and 7 strains of $P$. pungens were identified (Table 1).

All melting curve peak Tm values, which included values of controls and isolates for each taxon, namely $P$. calliantha $(\mathrm{n}=19)$, P. delicatissima/P. cf. arenysensis $(\mathrm{n}=18)$ and $P$. pungens $(\mathrm{n}=14)$, are illustrated in the box plot (Fig. 3). The Tm values among the three taxa were found to be significantly different using the Kruskal-Wallis test $(\mathrm{Hc}=60.4, \mathrm{p}<0.001)$. Furthermore, a posteriori pairwise Mann-Whitney comparisons showed that there was a significant difference between $P$. calliantha, P. delicatissima/P. cf. arenysensis, and P. pungens $(\mathrm{p}<0.001$ after the Bonferroni correction).

Pseudo-nitzschia spp. strains identified by the HRM assay were then verified by phylogenetic analyses based on LSU and ITS-5.8S rDNA sequences. All the strains analyzed using the HRM assay were sequenced and included in the phylogenetic analyses. Only, representative strains of the three NW Adriatic Pseudo-nitzschia spp. are shown.

Phylogenetic analyses of Pseudo-nitzschia spp. LSU and ITS-5.8S ribosomal genes. The final alignments of Pseudo-nitzschia spp. ribosomal gene sequences, as namely LSU and ITS-5.8S, with Fragilariopsis as an outgroup, were as follows: LSU was 529 bp in length $(A=25.8 \%, T=27.1 \%, C=17.2 \%, G=30 \%)$ with 515 total informative sites, excluding gaps, and 99 polymorphic sites, of which 65 were parsimony sites. ITS-5.8S was $890 \mathrm{bp}$ in length $(\mathrm{A}=27 \%, \mathrm{~T}=34.8 \%, \mathrm{C}=18.2 \%, \mathrm{G}=20 \%)$ with 468 total informative sites excluding gaps and 218 polymorphic sites, of which 245 were parsimony sites.

Based on single LSU and ITS-5.8S rDNA sequences, only minor differences between the NJ, MP, ML and Bayesian inference analyses were found; therefore, only the ML phylogenetic trees are presented. The LSU rDNA phylogeny that was obtained from 40 isolates of the Pseudo-nitzschia spp. showed that NW Adriatic representative strains, identified as $P$. pungens (CBA179 and CBA180) and P. calliantha (CBA192 and CBA194) by the HRM assay, clustered in the clades of the corresponding species. By contrast, Adriatic strains identified as $P$. delicatissima/P. cf. arenysensis by the HRM assay and sharing identical LSU sequences, grouped together in a well-supported clade of $P$. arenysensis, as a sister to a clade including $P$. delicatissima/P. micropora/P. dolorosa within the P. delicatissima complex (Figure S2). Only four representative strains (CBA159, CBA165, CBA163, CBA169) of Adriatic P. cf. arenysensis were shown. All these lineages were strongly supported by high bootstrap and posterior probability values.

The ITS-5.8S rDNA phylogeny that was obtained from 31 isolates of the Pseudo-nitzschia spp. showed similar tree topology to the LSU rDNA phylogeny, confirming that the NW Adriatic representative strains, identified as P. pungens (CBA179 and CBA180) and P. calliantha (CBA193 and CBA194) by the HRM assay grouped with these corresponding taxa, and all strains identified as $P$. delicatissima/P. cf. arenysensis by the HRM assay grouped into the clade of $P$. arenysensis, which separated after $P$. delicatissima. Only three representative strains of Adriatic $P$. cf. arenysensis were shown. Hence, these two clades diverged after P. micropora. All the clades were supported by high bootstrap and posterior probability values (Figure S3).

\section{Discussion}

In this study, a reliable, rapid and robust molecular qPCR HRM assay was developed in order to rapidly and accurately detect potentially harmful Pseudo-nitzschia species in cultured samples obtained from coastal water survey. This HRM method is based on a post PCR analysis, which differs from previous qPCR melt curve analyses ${ }^{13,30,51}$, because the amplicons produced by the qPCR are subjected to a thermal gradient with temperature increments of $0.1^{\circ} \mathrm{C} / \mathrm{sec}$ using sensitive instrumentation that ensures the absolute precision of the temperature increments. By continuously monitoring the fluorescence emitted by the Meltdoctor HRM Dye, it is possible to assess the exact melting temperature of the amplicon with a precision of $0.1^{\circ} \mathrm{C}$. Base differences and/or insertions or deletions of one or more bases are revealed, and this makes it possible to discriminate between amplicons and, consequently, between species. The genus specific primers were designed on a partial domain LSU rDNA sequence alignment including most representative Pseudo-nitzschia spp. species from the Mediterranean region in order to include a high level of genetic diversity. The variable D1-D3 region of LSU has been widely used for species-specific identification using various molecular approaches such as $\mathrm{qPCR}^{13,30}$, microarray ${ }^{32,34,52}$, and FISH or sandwich hybridization assay ${ }^{53-55}$. Within the LSU gene, we identified a variable inter-specific target, flanked by highly conserved regions, which was suitable for primer design and the relative production of specific amplicons of each HRM variant. The ITS regions were also explored for primer design; however, they showed too much variability to encompass target Pseudo-nizschia species. In fact, ITS regions of diatom species are also known to be highly variable at intra-species level ${ }^{56,57}$. The amplicon length was $130 \mathrm{bp}$ satisfying the HRM analysis conditions. The 

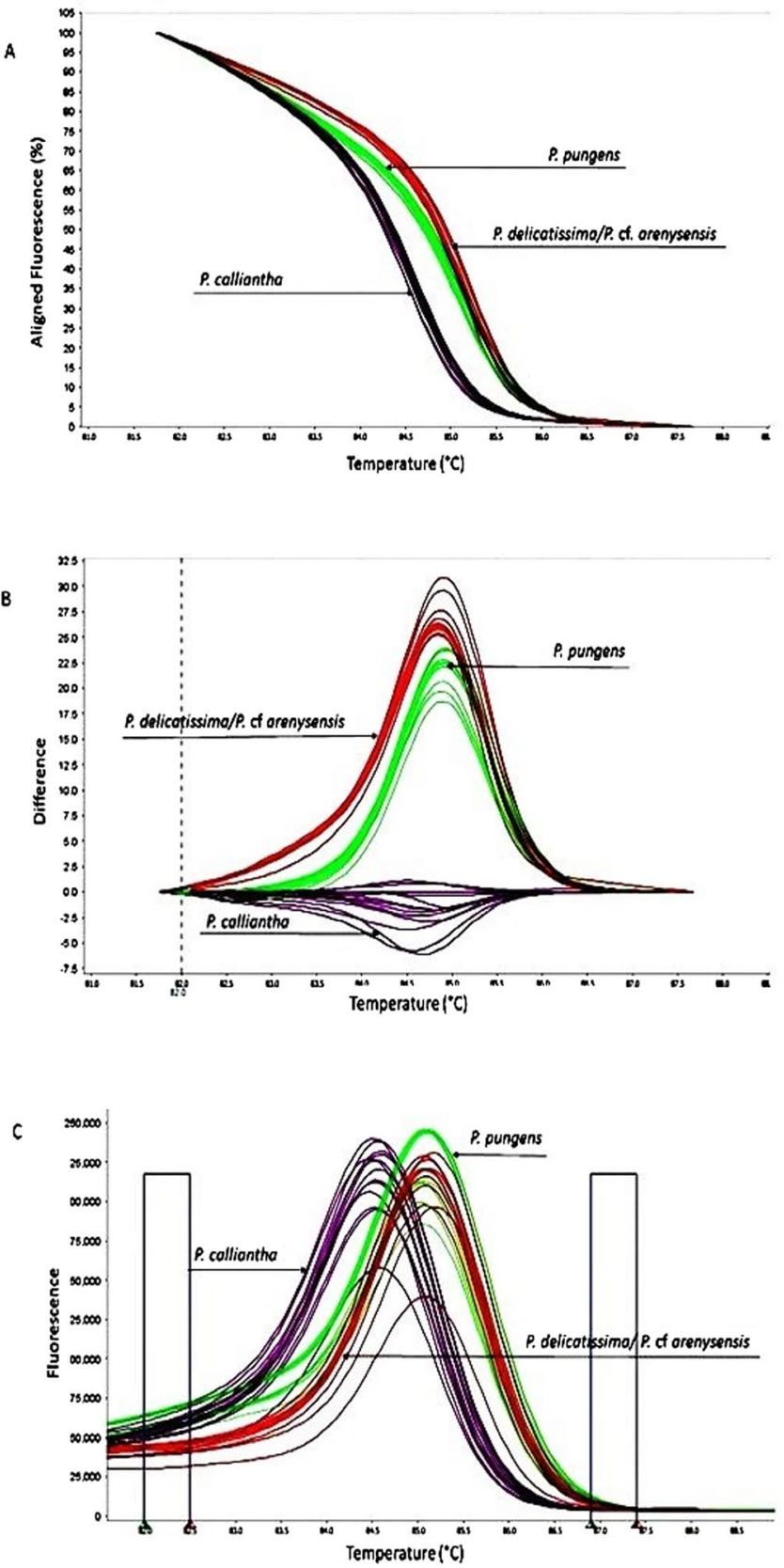

Figure 2. Melting curve variance of the $P$. calliantha $(\mathrm{n}=12$ strains), $P$. delicatissima/P. cf. arenysensis $(\mathrm{n}=10$ strains) and $P$. pungens ( $\mathrm{n}=7$ strains) in $(\mathbf{A})$ aligned, $(\mathbf{B})$ difference and $(\mathbf{C})$ derivative plot analyses; from left to right, vertical bars represent the pre and post - melt regions. A melting curve generated by a DNA positive control for each taxon was also included. Only one replicate of the HRM assay experiment for each strain is shown.

sequence variations within the analyzed region of the LSU gene allowed us to use the HRM assay for the identification of these isolates. In particular, $P$. delicatissima and $P$. cf. arenysensis constituting the $P$. delicatissima complex, showed no differences in their nucleotide sequences and their high resolution melting curves were identical. Other molecular approaches, such as dot-blot hybridization ${ }^{35}$, have also shown that these species share identical target LSU regions because of incomplete lineage sorting ${ }^{23}$. When the $P$. delicatissima complex sequence was selected as a reference in the pairwise alignment analysis, $P$. calliantha and $P$. pungens showed 5 and 7 nucleotides of difference, respectively. These sequence features allowed us to distinguish these species and/or complex using the HRM assay. The melting curves of all the isolates could be clustered into three groups. Identification of the Pseudo-nitzschia spp. was made by comparing their values to those of controls, with a confidence interval of between $96-100 \%$ for auto-called results. The resulting melt profile reflected the difference in the amplicons and/ or GC content in the $130 \mathrm{bp}$ amplicons. The HRM assay was applied to Pseudo-nitzschia spp. unidentified isolates collected in the NW Adriatic Sea during a survey period. Distinct species were identified among the isolates, 


\begin{tabular}{|c|c|c|c|}
\hline Strain & Species identified by HRM & Collection site & Sampling date \\
\hline CBA 172 & P. calliantha & Tavollo & 20 November 2014 \\
\hline CBA 173 & P. calliantha & Tavollo & 20 November 2014 \\
\hline CBA 181 & P. calliantha & Tavollo & 19 March 2015 \\
\hline CBA 183 & P. calliantha & Tavollo & 19 March 2015 \\
\hline CBA 189 & P. calliantha & Tavollo & 19 March 2015 \\
\hline CBA 191 & P. calliantha & Metauro & 20 March 2015 \\
\hline CBA 192 & P. calliantha & Metauro & 20 March 2015 \\
\hline CBA 193 & P. calliantha & Tavollo & 20 March 2015 \\
\hline CBA 194 & P. calliantha & Metauro & 20 March 2015 \\
\hline CBA 198 & P. calliantha & Tavollo & 13 January 2015 \\
\hline CBA 203 & P. calliantha & Tavollo & 13 January 2015 \\
\hline CBA 205 & P. calliantha & Tavollo & 13 January 2015 \\
\hline CBA 159 & P. delicatissima/P. cf. arenysensis & Tavollo & 20 November 2014 \\
\hline CBA 161 & P. delicatissima/P. cf. arenysensis & Tavollo & 20 November 2014 \\
\hline CBA 163 & P. delicatissima/P. cf. arenysensis & Tavollo & 20 November 2014 \\
\hline CBA 165 & P. delicatissima/P. cf. arenysensis & Tavollo & 20 November 2014 \\
\hline CBA 166 & P. delicatissima/P. cf. arenysensis & Tavollo & 20 November 2014 \\
\hline CBA 167 & P. delicatissima/P. cf. arenysensis & Tavollo & 13 January 2015 \\
\hline CBA 168 & P. delicatissima/P. cf. arenysensis & Tavollo & 13 January 2015 \\
\hline CBA 169 & P. delicatissima/P. cf. arenysensis & Tavollo & 13 January 2015 \\
\hline CBA 170 & P. delicatissima/P. cf. arenysensis & Tavollo & 13 January 2015 \\
\hline CBA 171 & P. delicatissima/P. cf. arenysensis & Tavollo & 13 January 2015 \\
\hline CBA 179 & P.pungens & Metauro & 20 March 2015 \\
\hline CBA 180 & P. pungens & Tavollo & 20 March 2015 \\
\hline CBA 182 & P. pungens & Tavollo & 19 March 2015 \\
\hline CBA 184 & P. pungens & Tavollo & 19 March 2015 \\
\hline CBA 186 & P. pungens & Tavollo & 19 March 2015 \\
\hline CBA 2S & P. pungens & Foglia & 10 February 2015 \\
\hline CBA 3S & P. pungens & Foglia & 10 February 2015 \\
\hline
\end{tabular}

Table 1. List of Pseudo-nitzschia spp. strains isolated from the NW Adriatic Sea $3000 \mathrm{~m}$ off the coast. The strains were analyzed and subsequently identified using the HRM assay.

specifically $P$. calliantha (12 isolates), $P$. pungens (7 isolates) and $P$. delicatissima/P. cf. arenysensis (10 isolates). No cross-reactivity or melt curve overlapping among the various species-specific DNAs was obtained. The Tm values were significantly different among the three identified variants of the Pseudo-nitzschia. Phylogenetic analyses of the LSU and ITS-5.8S rDNA sequences of Pseudo-nitzschia spp. isolates identified by the HRM assay confirmed their species-specific taxonomical designation. The phylogenetic inference obtained from rDNA sequences was robust demonstrating that the distinct clades of $P$. calliantha, $P$. pungens, $P$. cf. arenysensis that were included in the $P$. delicatissima complex were supported by high bootstrap values and Bayesian inferences. P. delicatissima is a cryptic species complex, comprising different genetic lineages ${ }^{20,23,58}$, including P. arenysensis. Therefore, the HRM assay was able to identify the $P$. delicatissima complex without discriminating the species because of a lack of SNPs in the amplicon between toxic $P$. delicatissima and non-toxic $P$. arenysensis. However, it has already been proven that in the NW Adriatic Sea, P. delicatissima, as well as P. arenysensis strains are non- toxic or have low toxicity ${ }^{13}$, ${ }^{59}$. In any case, further investigation is needed to better characterize the Adriatic $P$. cf. arenysensis. In fact, this phylogenetic clade was distinct from the $P$. arenysensis found in other Mediterranean areas, showing that the $P$. delicatissima complex still includes cryptic or semi-cryptic species.

This post PCR HRM analysis can be performed rapidly and with high processivity. Several cultured samples can be examined in one workday, unlike $\mathrm{qPCR}$ or sequence analyses, which are more time intensive. In addition, the HRM assay is less costly than microarrays, which require the development of probe devices, or qPCR analysis. The HRM assay depends on available reference genotypes, and it analyzes monoclonal cultures of the species under investigation. Hence, to account for the potential intra-specific genetic variability of the Pseudo-nitzschia spp., as many Pseudo-nitzschia DNA controls as possible will be developed, a broader range of Pseudo-nitzschia species diversity will be tested in the area under investigation. The HRM assay is likely to be feasible and applicable given that distinct melt curves of target Pseudo-nitzchia species have been obtained accurately based on different Tm and silhouettes of the curves for each species or complex.

In this area of the Mediterranean Sea, there is widespread high intensity aquaculture farming. Recent findings regarding DA toxin accumulation in shellfish and clonal strains found to produce DA highlight the necessity of developing methods able to accurately and rapidly determine how many species of Pseudo-nitzschia are present and which are actually producing DA. This information could be of great importance in the assessment of the potential risk of real toxic events in target coastal areas including the Adriatic one investigated in this study. 


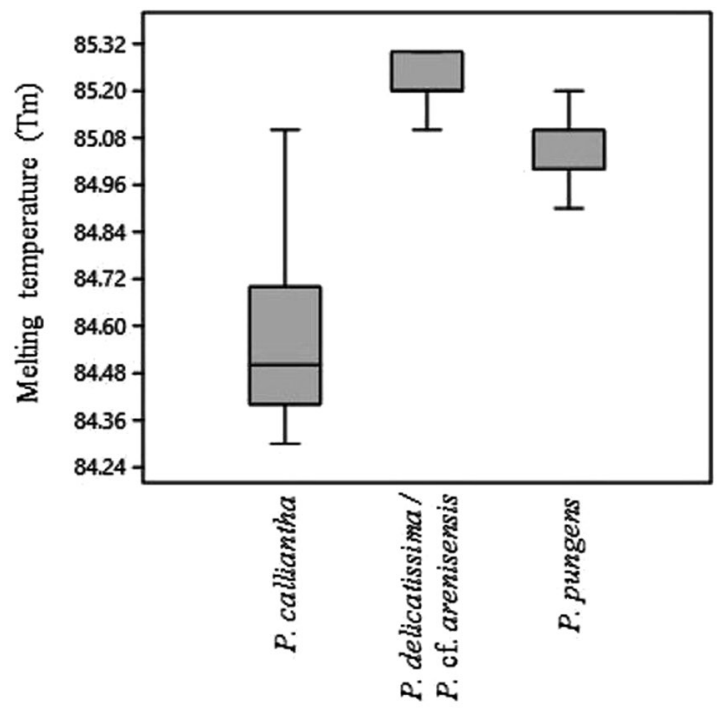

Figure 3. Box plot showing melting curve temperatures (Tm) of Pseudo-nitzschia spp. isolates collected in the NW Adriatic Sea and used in this study. The Kruskall Wallis test shows significant differences in average Tm values among species $(\mathrm{p}<0.001)$.

The post PCR HRM assay developed in this study appears to be a promising tool for simultaneous detection and identification of the Pseudo-nitzschia spp. coupled with analytical detection of DA. The assay offers several advantages: it is specific, reproducible and rapid when applied to several simultaneously processed cultured samples. Future sampling of the numerous potentially harmful species in the Mediterranean Sea could take advantage of the application range of the HRM assay.

\section{References}

1. Jin, X., Gruber, N., Dunne, J. P., Sarmiento, J. L. \& Armstrong, R. A. Diagnosis the contribution of phytoplankton functional groups to the production and export of particulate carbon, $\mathrm{CaCO} 3$, and opal from global nutrient and alkalinity distributions. Global Biogeochem. Cycles 20, GB2015 (2006).

2. Trainer, V. L. et al. Pseudo-nitzschia physiological ecology, phylogeny, toxicity, monitoring and impacts on ecosystem health. Harmful Algae 14, 271-300 (2012).

3. Lundholm, N. et al. Cryptic and pseudo-cryptic diversity in diatoms-with descriptions of Pseudo-nitzschia hasleana sp. nov. and $P$. fryxelliana sp. nov. J. Phycol 48, 436-454 (2012).

4. Glibert, P. M. \& Burkholder, J. M. Harmful algal blooms and eutrophication: "strategies" for nutrient uptake and growth outside the Redfield comfort zone. Chinese J. Oceanol. Limnol 29, 724-738 (2011).

5. Scholin, C. A. et al. Mortality of sea lions along the central California coast linked to a toxic diatom bloom. Nature 403, 80-84 (2000).

6. Lefebvre, K. A., Bargu, S., Kkhefer, T. \& Slver, M. W. Fm sanddabs to blue whales: the pervasiveness of domoic acid. Toxicon 40, 971-977 (2002).

7. Bejarano, A. C., Van Dolan, F. M., Gulland, F. M., Rowles, T. K. \& Schwacke, L. H. Production and toxicity of the marine biotoxin domoic acid and its effects on wildlife: a review. Hum. Ecol. Risk Assess. 14, 544-567 (2008).

8. Bates, S. S. et al. Pennate diatom Nitzschia pungens as the primary source of domoic acid, a toxin in shellfish from eastern Prince Edward Island, Canada. Can. J. Fish. Aquat. Sci. 46, 1203-1215 (1989).

9. Sahraoui, I., Bates, S. S., Bouchouicha, D., Hadj Mabrouk, H. \& Sakka Hlaili, A. Toxic and potentially toxic Pseudo-nitzschia populations in Bizerte Lagoon (Tunisia, SW Mediterranean) during 2006-2007, and first report of domoic acid production by Pseudo-nitzschia brasiliana Lundholm. Hasle, \& G. A. Fryxell. Diatom Res. 26, 293-303 (2011).

10. Cerino, F. et al. The alternation of different morphotypes in the seasonal cycle of the toxic diatom Pseudo-nitzschia galaxiae. Harmful Algae 4, 33-48 (2005).

11. Orsini, L. et al. Toxic Pseudo-nitzschia multistriata (Bacillariophyceae) from the Gulf of Naples: Morphology, toxin analysis and phylogenetic relationships with other Pseudo-nitzschia species. Eur. J. Phycol. 37, 247-57 (2002).

12. Moschandreou, K. K., Papaefthimiou, D., Katikou, P., Kalopesa, E., Panou, A. \& Niko-laidis, G. Morphology, phylogeny and toxin analysis of Pseudo-nitzschia pseudodelicatissima (Bacillariophyceae) isolated from the Thermaikos Gulf, Greece. Phycologia 49, 260-273 (2010).

13. Penna, A. et al. Toxic Pseudo-nitzschia spp. in the northwestern Adriatic Sea: characterization of species composition by genetic and molecular quantitative analyses. J. Plankton Res. 35, 352-366 (2013).

14. DeGobbis, D. \& Gilmartin, M. Nitrogen, phosphorus, and biogenic silicon budgets for the northern Adriatic Sea. Oceanol. Acta 13, $31-45(1990)$

15. Aubry, B. F., Berton, A., Bastianini, M., Socal, G. \& Acri, F. Phytoplankton succession in a coastal area of the NW Adriatic, over a 10-year sampling period (1990-1999). Cont. Shelf Res. 24, 97-115 (2004).

16. Socal, G. et al. Hydrological and biogeochemical features of the northern Adriatic Sea in the period 2003-2006. Mar. Ecol 29, 449-468 (2008).

17. Totti, C. et al. Seasonal variability of phytoplankton populations in the middle Adriatic sub-basin. J. Plankton Res 22, 1735-1756 (2000).

18. Penna, A., Ingarao, C., Ercolessi, M., Rocchi, M. \& Penna, N. Potentially harmful microalgal distribution in an area of the NW Adriatic coastline: sampling procedure and correlations with environmental factors. Estuar. Coast. Shelf Sci. 70, 307-316 (2006). 
19. Maric, D. et al. Blooms of the potentially toxic diatom Pseudo-nitzschia calliantha Lundholm, Moestrup \& Hasle in coastal waters of the northern Adriatic Sea (Croatia). Estuar. Coast. Shelf Sci. 92, 323-331 (2011).

20. Amato, A., Ludeking, A. \& Kooistra, W. H. C. F. Intracellular domoic acid production in Pseudo-nitzschia multistriata isolated from the Gulf of Naples (Tyrrhenian Sea, Italy). Toxicon 55, 157-161 (2010).

21. Pistocchi, R. et al. Toxin levels and profiles in microalgae from the North-Western Adriatic Sea-15 years of studies on cultured species. Mar. Drugs 10, 140-162 (2012).

22. Hasle, G. R. \& Lundholm, N. Pseudo-nitzschia seriata f. obtuse (Bacillariophyceae) raised in rank based on morphological, phylogenetic and distributional data. Phycologia 44, 608-619 (2005).

23. Lundholm, N. et al. Inter- and intraspecific variation of the Pseudo-nitzschia delicatissima complex (Bacillariophyceae) illustrated by rRNA probes, morphological data and phylogenetic analyses. J. Phycol. 42, 464-481 (2006).

24. Ajani, P., Murray, S., Hallegraeff, G., Brett, S. \& Armand, L. First reports of Pseudo-nitzschia micropora and P. hasleana (Bacillariaceae) from the Southern Hemisphere: Morphological, molecular and toxicological characterization. Phycol. Res. 61, 237-248 (2013).

25. Ruggiero, M. V. et al. Diversity and temporal pattern of Pseudo-nitzschia species (Bacillariophyceae) through the molecular lens. Harmful Algae 42, 15-24 (2015).

26. Sarno, D., Kooistra, W. H. C. F., Medlin, L. K., Percopo, I. \& Zingone, A. Diversity in the genus Skeletonema (Bacillariophyceae). II. An assessment of the taxonomy of S. costatum-like species with the description of four new species. J. Phycol 41, 151-176 (2005).

27. Amato, A. et al. Reproductive isolation among sympatric cryptic species in marine diatoms. Protist 158, 193-207 (2007).

28. Nanjappa, D., Audic, S., Romac, S., Kooistra, W. H. C. F. \& Zingone, A. Assessment of species diversity and distribution of an ancient diatom lineage using a DNA metabarcoding approach. PLoS One 9(8), e103810 (2014).

29. Fitzpatrick, E., Caron, D. A. \& Schnetzer, A. Development and environmental application of a genus-specific quantitative PCR approach for Pseudo-nitzschia species. Mar. Biol. 157, 1161-1169 (2010).

30. Andree, K. B. et al. Quantitative PCR coupled with melt curve analysis for detection of selected Pseudo-nitzschia spp. (Bacillariophyceae) from the northwestern Mediterranean Sea. Appl. Environ. Microbiol. 77, 1651-1659 (2011).

31. Hubbard, K. A., Rocap, G. \& Armbrust, E. V. Inter- and intraspecific community structure within the diatom genus Pseudo-nitzschia (Bacillariophyceae). J. Phycol. 44, 637-649 (2008).

32. Galluzzi, L. et al. Development of an oligonucleotide microarray for the detection and monitoring of marine dinoflagellates. J. Microbiol. Meth. 84, 234-242 (2011).

33. Smith, M. W. et al. High resolution microarray assay for rapid taxonomic assessment of Pseudo-nitzschia spp. (Bacillariophyceae) in the field. Harmful Algae 19, 169-180 (2012).

34. Barra, L., Ruggiero, M. V., Sarno, D., Montresor, M. \& Kooistra, W. H. C. F. Strengths and weaknesses of microarray approaches to detect Pseudo-nitzschia species in the field. Environ. Sci. Poll. Res 20, 6705-6718 (2013).

35. Barra, L., Ruggiero, M. V., Chen, J. \& Kooistra, W. H. C. F. Specificity of LSU rRNA-targeted oligonucleotide probes for Pseudonitzschia species tested through dot-blot hybridization. Environ. Sci. Poll. Res 21, 548-557 (2014).

36. Penna, A. \& Galluzzi, L. The quantitative real-time PCR applications in the monitoring of marine harmful algal bloom (HAB) species. Environ. Sci. Poll. Res 20, 6851-6862 (2013).

37. Koyuncu, F., Tas, S., Müftüoğlu, A. E. \& Uzonur, I. Genetic heterogeneity characterization of a P. minimum bloom sample using DNA melt-curve analysis, high resolution melt-curve analysis and real-time RAPD-PCR. Fresenius Environ. Bull 19, 2404-2410 (2010).

38. Al-Kandari, M. A., Highfield, A. C., Hall, M. J., Hayes, P. \& Schroeder, D. C. Molecular tools separate harmful algal bloom species, Karenia mikimotoi, from different geographical regions into distinct sub-groups. Harmful Algae 10, 636-643 (2011).

39. Granados-Cifuentes, C. \& Rodriguez-Lanetty, M. The use of high-resolution melting analysis for genotyping Symbiodinium strains: a sensitive and fast approach. Mol. Ecol. Res 11, 394-399 (2011).

40. Ceccarelli, M., Galluzzi, L., Migliazzo, A. \& Magnani, M. Detection and Characterization of Leishmania (Leishmania) and Leishmania (Viannia) by SYBR green- based real-time PCR and high resolution melt analysis targeting kinetoplast minicircle DNA. PLoS One 9(2), e88845 (2014).

41. Guillard, R. R. L. Culture of phytoplankton for feeding marine invertebrates in Culture of Marine Invertebrate Animals. (eds W. L. Smith \& M. H. Chanley) 26-60 (Plenum Press 1975)

42. Moschandreou, K. K. et al. Inter- and intra-specific diversity of Pseudo-nitzschia (Bacillariophyceae) in the northeastern Mediterranean. Eur. J. Phycol. 47, 321-339 (2012).

43. Relini, G. Checklist della Flora e della Fauna dei Mari Italiani (Parte II). Biol. Mar. Mediterr. 17(Suppl. 1), 387-828 (2010).

44. Hall, T. A. BioEdit: a user-friendly biological sequence alignment editor and analysis program for Windows 95/98/NT. Nucl. Acids. Symp. Ser. 41, 95-98 (1999).

45. Ye, J. et al. Primer-BLAST: a tool to design target-specific primers for polymerase chain reaction. BMC Bioinformatics 13, 134 (2012).

46. Scholin, C. A., Herzog, M., Sogin, M. \& Anderson, D. M. Identification of group and strain-specific genetic markers from globally distributed Alexandrium (Dinophyceae). II. Sequence analysis of fragments of the LSU rRNA gene. J. Phycol. 30, 999-1011 (1994).

47. Adachi, M., Sako, Y. \& Ishida, Y. Restriction fragment length polymorphism of ribosomal DNA internal transcribed spacer and $5.8 \mathrm{~S}$ regions in Japanese Alexandrium species (Dinophyceae). J. Phycol. 30, 857-863 (1994).

48. Pin, L. C., Teen, L. P., Ahmad, A. \& Usup, G. Genetic Diversity of Ostreopsis ovata (Dinophyceae) from Malaysia. Mar. Biotechnol 3, 246-255 (2001).

49. Tamura, K. et al. MEGA5: molecular evolutionary genetics analysis using maximum likelihood, evolutionary distance, and maximum parsimony methods. Mol. Biol. Evol. 28, 2731-2739 (2011).

50. Ronquist, F. \& Huelsenbeck, J. P. MrBayes 3: Bayesian phylogenetic inference under mixed models. Bioinformatics 19, 1572-1574 (2003).

51. Zhang, F. \& Li, Z. Detection and quantification of cultured marine Alexandrium species by real-time PCR. World J. Microbiol. Biotechnol. 28, 3255-3260 (2012).

52. Dittami, S. M., Pazos, Y., Laspra, M. \& Medlin, L. K. Microarray testing for the presence of toxic algae monitoring programme in Galicia (NW Spain). Environ. Sci. Pollut. Res. 20, 6778-6793 (2013).

53. Scholin, C. A. et al. DNA probes and a receptor-binding assay for detection of Pseudo-nitzschia (Bacillariophyceae) species and domoic acid activity in cultured and natural samples. J. Phycol 35, 1356-1367 (1999).

54. Toebe, K. Whole cell hybridisation for monitoring harmful marine microalgae. Environ. Sci. Pollut. Res. 20, 6816-6823 (2013).

55. Scholin, C. et al. Remote detection of marine microbes, small invertebrates, harmful algae, and biotoxins using the environmental sample processor (ESP). Oceanography 22, 158-167 (2009).

56. D'Alelio, D. et al. Internal transcribed spacer polymorphism in Pseudo-nitzschia multistriata (Bacillariophyceae) in the Gulf of Naples: recent divergence or intraspecific hybridization? Protist 160, 9-20 (2009).

57. McDonald, S. M., Sarno, D. \& Zingone, A. Identifying Pseudo-nitzschia species in natural samples using genus-specific PCR primers and clone libraries. Harmful Algae 6, 849-860 (2007).

58. Quijano-Scheggia, S. I. et al. Morphology, physiology, molecular phylogeny and sexual compatibility of the cryptic Pseudo-nitzschia delicatissima complex (Bacillariophyta), including the description of P. arenysensis sp. Nov. Phycologia 48, 492-509 (2009).

59. Quijano-Scheggia, S. et al. Pseudo-nitzschia species on the Catalan coast: characterization and contribution to the current knowledge of the distribution of this genus in the Mediterranean Sea. Sci. Mar. 74, 395-410 (2010). 


\section{Acknowledgements}

Financial support was provided by the Regione Marche - Project of coastal monitoring n. 49 of 23/12/2013 and ENPI (European Neighborhood and Partnership Instrument) CBCMED (Cross Border Cooperation in the Mediterranean) M3-HABs II-B/2.1/0096. The authors are very grateful to Dr. Luca Galluzzi for his role in the stimulating scientific discussion around this investigation and Dr. Samuela Capellacci for providing several strains.

\section{Author Contributions}

L.P. and A.P. contributed to the conception and design of the study; L.P. carried out the study. L.P., S.C. and F.P. performed the statistical analyses. F.A. carried out the sequence analysis. A.P. performed the phylogenetic analyses. All authors were involved in the manuscript preparation and revision approval of the final version of the manuscript.

\section{Additional Information}

Supplementary information accompanies this paper at doi:10.1038/s41598-017-04245-Z

Competing Interests: The authors declare that they have no competing interests.

Publisher's note: Springer Nature remains neutral with regard to jurisdictional claims in published maps and institutional affiliations.

(c) (i) Open Access This article is licensed under a Creative Commons Attribution 4.0 International License, which permits use, sharing, adaptation, distribution and reproduction in any medium or format, as long as you give appropriate credit to the original author(s) and the source, provide a link to the Creative Commons license, and indicate if changes were made. The images or other third party material in this article are included in the article's Creative Commons license, unless indicated otherwise in a credit line to the material. If material is not included in the article's Creative Commons license and your intended use is not permitted by statutory regulation or exceeds the permitted use, you will need to obtain permission directly from the copyright holder. To view a copy of this license, visit http://creativecommons.org/licenses/by/4.0/.

(c) The Author(s) 2017 